\title{
Influence of Online Tax Filing on Tax Compliance among Small and Medium Enterprises in Nakuru Town, Kenya
}

\author{
Ondara Thomas Gwaro ${ }^{1}$, Dr. Kimani Maina ${ }^{2}$, Dr. Josphat Kwasira ${ }^{3}$ \\ ${ }^{1}$ Master of Business Administration (Finance) student at Jomo Kenyatta University of Agriculture and \\ Technology, Nakuru Campus, Kenya. \\ ${ }^{2}$ Lecturer at Jomo Kenyatta University of Agriculture and Technology, Nakuru Campus, Kenya. \\ ${ }^{3}$ Senior lecturer at Jomo Kenyatta University of Agriculture and Technology, Nakuru Campus, Kenya. \\ Jomo Kenyatta University of Agriculture and Technology P.O Box 62000-00200, Nakuru
}

\begin{abstract}
The Kenya Revenue Authority has introduced online filing through the iTax system that replaced the Integrated Tax Management Systems. The online filing of tax returns introduces benefits that were not possible through manual filing of the tax returns. These benefits include the element of convenience to the taxpayer, reduced costs on the revenue authority, and quality data on tax returns due to elimination of data entry errors associated with manual filing. This study aims to assess the level of awareness regarding online filing of tax returns in the context of the Small and Medium Enterprises in Nakuru. The Small and Medium Enterprises in Nakuru Central Business District have been chosen owing to the fact that Nakuru town is the fastest growing town in East and Central Africa due to the high number of Small and Medium Enterprises in the town. The specific objectives of the study included examination of the effect of computer literacy on tax compliance among Small and Medium Enterprises in Nakuru, examination of the impact of online tax filing on tax compliance among Small and Medium Enterprises and an examination of perceived security on tax compliance. The study is based on four theories as part of the theoretical framework, that is, the Theory of Technological Acceptance Model, Unified Theory of Acceptance and Use of Technology, Theory of Reasoned Action and Diffusion of Innovation Theory. These theories deal with the factors influencing the adoption of new information systems such online filing. The study utilized the survey descriptive research design in which quantitative data was collected through use of primary data collection techniques. Primary data was collected using questionnaires. A sample size of 100 respondents from the Small and Medium Enterprises in Nakuru was utilized. The study found amongst the independent variables only the computer literacy had significant effect on the influence tax compliance levels amongst Small and Medium Enterprises in Nakuru.The multiple correlation effect of 0.954 indicates a relatively strong positive relationship effect between the three independent variables and the dependent variable. The coefficient of determination ( $R$ Square) indicates the variance on the dependent variable attributed to the three independent variables. In this context, the coefficient of determination $(R$ Square) of 0.911 indicates that the three independent variables contributed to $91.1 \%$ of the variance in the dependent variable.
\end{abstract}

Keywords: Tax Compliance, Small and Medium Enterprises, Online Tax Filing

\section{Introduction}

Governments are adopting Information and Communications Technologies (ICT) to improve on service delivery, enhance convenience among citizenry and increase accessibility to government information is on the rise (Azmi \& Kamarulzaman, 2010). Introduction of the electronic tax filing is a major form of electronic government services (Lai \& Choong, 2010). The various governments in the world are also introducing electronic tax filing in order to achieve greater tax administrative and compliance efficiency (Mandola, 2013). Governments around the world are introducing electronic filing of the tax returns due to the various advantages associated with it (Young, 2012).

Among these advantages include convenience of the taxpayers as they are able to file tax returns at home or cybercafés, and eliminates or reduces errors associated with manual filing as the system auto checks the application (Osebe, 2013). Other advantages include reduced workload and cost for the tax collector among amongst others (Simiyu, 2013). However, there are challenges associated with the online filing including taxpayer's perception, challenges associated with learning the electronic filing system from service provider, limited accessibility of internet infrastructure and electronic filing system down times (Azmi \& Bee, 2011). Several countries have had different experiences in regards to the electronic filing of tax returns.

Electronic filling of tax returns was first done in the Unites States of America in 1986 (Lai \& Choong, 2010). Several countries in both the developing and developed countries have since adopted the electronic filing system. For example, Uganda through the Uganda Revenue Authority (URA) introduced Electronic filling of tax in 2009 (Auyat, 2013). In South Africa, the services were introduced in 2003 by the South African Revenue 
Services (SARS) with significant developments in 2006 while in Malaysia, the services was implemented by the Inland Revenue Authority (Ferreira, 2008; Razak, 2009).

In South Africa, there are three ways of tax returns including the manual returns, electronic filling (e filing) of tax returns and electronic based form filing of tax returns (Ferreira, 2008). The manual tax returns include filing the manual tax return forms from the South African Revenue Services (SARS) and returning the completed forms to the authority. The electronic form filing involves filling the manual equivalent of the form electronically and printing the form for submission to the authority(Ibrahim, 2012).

The E filling of the tax returns in South Africa involves the electronic filling and submission of the tax returns. There are several benefits that have been realized in the South African context in regards to online tax returns. These includes extended time for tax payers to submit their returns that is up to January of the preceding year as opposed to October of a current year for the tax returns (Ferreira, 2008). The major challenges with the e filing of the tax returns in South Africa included software requirements of the SARS program that utilized adobe acrobat 8 software. This software required at least a Pentium 11 computer to run which was not widely available in South Africa at the time of e filing introduction. The issue of comprehensive online help menus was a challenge as well as the navigation of the e filing site (Lai \& Choong, 2010).

In Malaysia, the Inland Revenue Board (IRB) introduced the electronic filling of the returns (e filing) (Razak, 2009). The E filling in Malaysia involved four basic steps that is enrollment and verification of the digital signature, the entering of the gross earnings, relief and deductions before the system automatically calculates the tax amount due. The IRB receives the submission electronically and the verified tax form returned emailed back to the taxpayer (Razak, 2009). Razak (2009) notes that the challenges encountered in the use of the e filing in Malaysia included technological challenges such as standards, data integration, legacy maintenance, privacy and security.

In Kenya, the earliest form of the online filing of tax returns was through the implementation of the Integrated Tax Management System (ITMS) in 2013. This was to facilitate the online payments of Value Added Tax (VAT), Cooperate Tax amongst others (Lukorito, 2012). The ITMS also connected the Electronic Tax Registers (ETR) devices (registers) to enable simplification of the VAT declarations. The ITMS enabled the taxpayers to undertake electronic filling. In the context of the system requirements, the ITMS required internet explorer 7 or higher of Mozilla Firefox 3.0.3 (Mandola, 2013). Kenya Revenue Authority (KRA) was to later phase out the ITMS and replaced it with the iTax system. The iTax enabled the taxpayer to undertake internet based registration, filing, paying and status inquiries with real time monitoring of the accounts (Mandola, 2013).

The electronic filing or online filing of tax returns is a general term for electronic filing or electronic lodgment or electronic declaration of tax returns through submission of tax data to a taxing authority in a computer file format through an internet connection (Ibrahim, 2012). On the other hand, Mandola (2013) defines electronic filing as an internet based system that enables the taxpayers to register and submit their tax returns over the internet. The platform or system could have an inbuilt software that has been pre-approved by the relevant tax authority to assist the taxpayers in calculating and consequently submit the correct amount of tax due (Mandola, 2013). The e-filing incorporates the process of registration, tax preparation, tax filing and tax payment (Lukorito, 2012). The taxpayer requires access to a computer, the tax software, a reliable internet connection and the knowledge to utilize the electronic filing (Hussein, Mohamed, Ahlan, Mahmud, \& Aditiawarman, 2010).

Ada (2009) classifies the tax administration into either the British or American Model. The British model assumes the incompetence of the tax payers and hence audits and independently verifies the supplied data on tax returns (Nakiwala, 2010). On the other hand, the American model runs on a voluntary compliance system which assumes the competence of the taxpayer and hence only independently verifies about $5 \%$ of the tax returns (Auyat, 2013). There are however heavy penalties for non-compliance (Auyat, 2013).

There are several advantages associated with the online tax filing including convenience as the filing can be done any time (day and night) and within one owns comfort e.g. at home (Geetha \& Sekar, 2012). There is also an element of the certainty of delivery and quick confirmation of the delivery as the online tax system confirms successful receipt of the taxpayers' submission. The online tax returns also eliminates data entry errors as the system automatically ensures that the data has been filled in the correct places(Hussein et al., 2010). Finally, document handling and storage is easier (Lukwata, 2011).

According to Ada (2009) taxation is the enforced proportional contributions from persons and property, levied by the state, by the virtue of its sovereignty, for the support of government and for all public needs. On the other hand Muhangi (2012) defines tax as a compulsory level imposed by government ( central or local) on the profit, income, wealth or consumption (e.g. sales or VAT) of an individual or estate through trustee or executor and corporate organization. Auyat (2013) further defines tax as a financial charge or other levy imposed upon a taxpayer (an individual or non-individuals) by a state or functional equivalent of a state, such that failure to pay is punishable by law. Auyat (2013) further defines tax as compulsory contribution from the person to government to defray the expenses incurred uncommon interest of all without reference to special 
benefit concurred. In summary, tax can be defined as the compulsory contribution levied by a sovereign power on the incomes, profits, goods, services or properties of individuals or corporate persons, trusts and settlements, which when collected, are used for carrying out government functions (Ada, 2009; Auyat, 2013; Muhangi, 2012).

There are several element of tax including the tax base, tax rate and tax yield (Ofori, 2009). The tax base is the legal description of an object on which tax is imposed or charged which can be the income of the taxpayer, gain from certain activities he engaged in, property or asset owned or some services received (Simiyu, 2013). On the other hand, the tax rate is the proportion of tax base that is payable as tax while tax yield is the total amount of revenue generated from tax (Ramoo, 2006). There are two tax classifications that is the direct versus indirect taxes and the proportional versus progressive loans (Odongo, 2014). The direct taxes are those that affect the individual directly through a deduction from earnings. On the other hand, the indirect taxes are those that are paid to the government by an intermediary and then passed on to the final user by including the tax in the final price (Nakiwala, 2010). Examples of direct taxes include income tax, property tax etc. On the other hand, the examples of indirect taxes include export and import duties, excise and local production, value added tax (VAT) and others (Ofori, 2009). The tax is said to be progressive if when with increasing income the tax liability not only increases in absolute terms but also proportionate to income (Simiyu, 2013). On the other hand, Ada (2009) defines proportional tax as form of tax that assesses a taxpayer to tax at flat rate on his total assessable income and as such the tax is payable proportional to the taxpayer's income. The progressive tax is a form of tax that is graduated as it applies to higher rates of tax as income increases (Ferreira, 2008).

According to Ssetuba (2012), tax compliance is the ability to pay taxes on time and timely reporting of the correct tax information. Other definitions of tax compliance concentrate on the accuracy of the information contained in the tax returns and the cost of making the tax returns. For example, Auyat (2013) defines tax compliance as the supply of accurate and timely lodgment of income tax return together with the required payments whenever due. There are two types of tax compliance; voluntary and involuntary tax compliance (Mandola, 2013). The voluntary tax compliance requires no state enforcement for the taxpayers to comply with the tax requirements in contrast to the involuntary tax compliance (Hussein et al., 2010).

Tax compliance is concerned on the timely and accurate submission of tax remittance information to the revenue authority. The online filing system has a direct impact on the tax compliance levels (Nakiwala, 2010). The system ensures that the taxpayer has filled all the required mandatory fields before allowing him to proceed to the next level. This has the effect of ensuring that the revenue authority receives relatively high quality data compared to the manual returns of the data (Nakiwala, 2010). The online filing of the tax returns ensures that there is lack of inconsistencies, missing information and unintentional errors (Mandola, 2013).

SMEs are faced with numerous challenges in the context of taxation. For example, Odongo (2014) found tax compliance levels among the SMEs in Uganda to be very low. There are several factors that led to low tax compliance levels in Uganda including poor book keeping, low sales turn overs, and frequent ownership changes of SMEs (Nakiwala, 2010). Other challenges include large proportion of SMEs who are ignorant of taxation processes and computations, and lack of comprehensive sensitization programmes by the Uganda Revenue Authority (URA) (Odongo, 2014).

There are challenges associated with the tax compliance levels among the SMEs in Kenya due to the nature of the firms (Simiyu, 2013). The turnover tax in Kenya introduced through the Finance Act of 2007 specifically targets the SMEs especially those with less than 5 million annual gross income (Osebe, 2013). Some of the challenges facing the taxation of the SMEs in Kenya include the fact that small businesses are normally owned by the owners who are also in charge of the accounting book (Muhangi, 2012). There is thus less incentive to comply with tax requirements.

\section{Theoretical Review}

\section{Literature Review}

The theoretical framework is going to be based on the Theory of Technological Acceptance Model (TUM). The theory of TAM was formulated in 1989 as a derivative of the Theory of Reasoned Action (TRA) in an attempt to explain the user acceptance and adoption of new technology (Hussein et al., 2010). The key features of the TAM is the perceived ease of use and usefulness .The perceived usefulness is defined as the degree to which a person believes that a particular technology will enhance his performance (Azmi \& Bee, 2011). On the other hand, the perceived ease of use is the degree to which the person believes that using a particular system will be free from of effort. The Behavioural Intent is the extent to which an individual intends to perform a specific behaviour (Ramoo, 2006). The TAM theory argues that perceived usefulness and perceived ease of use influences the computer user's intention and actual usage of anew information system (Hussein et al., 2010). There are varied thoughts among the scholars on whether the perceived usefulness or the perceived ease of use is the primary determinant in the usage of a new information system (Azmi \& Bee, 2011). Azmi \& Bee (2010) included perceived risk in their study The Acceptance of the e-Filing System by Malaysian 
Taxpayers: A Simplified Model. The perceived risk was being used increasingly in studies touching on e governance. In their model, the y introduced perceived risk with two facets; privacy risk and performance risk. Azmi \& Bee (2010) defined perceived risk as taxpayers' perception on the reliability of the system's usefulness/functionality and the control of their personal data information in an online environment. They further defined privacy risk as the concerns over the safeguard of various types of data that are collected during taxpayers' interaction with the e-filing system due to concerns on third parties accessing their personal information. The performance risk refers to the possibility of the system failing to deliver on its promises. In the study on the interaction between the perceived risk and the traditional perceived usefulness and the perceived ease of use, Azmi \& Bee (2010) argue that complex systems that take time to learn are considered risk to adopt and use.

\section{Impact of Computer Literacy Levels on Tax Compliance}

The computer literacy level and accessibility to internet infrastructure has a direct impact towards the use of the online tax returns (Auyat, 2013). The online tax services are often internet based platforms and basic knowledge of the usage of the internet is required (Azmi \& Bee, 2010). In this context, the user must be able to self-navigate on the web-based platform with minimal difficulties if any and use the self-help menus available in the website (Hussein et al., 2010). Mandola (2013) noted that half the sampled respondents in her study on the adoption of ITMS system indicated that any online e government services needs to be easy to use to enable even those with little internet experience to effectively use the service. In this context, she found a correlation between an individual's internet experience, the availability and access to internet facilities, and the ease in which the potential user can learn and use e government services such as online filing.

The lack of the appropriate computer literacy levels therefore makes online tax filing expensive (Osebe, 2013). Lack of the ability to use the e filing system quickly and efficiently or lack of understanding the type of information required by the online tax filing system forces taxpayers to engage third parties (Mandola, 2013). These third parties could be the cybercafé attendants and would charge premium for such services (Odongo, 2014). The net effect is that it becomes expensive to use online tax filing in contexts where the taxpayer is computer illiterate hence a preference for the manual filing (Ofori, 2009). The taxpayer may also opt to execute the electronic filling on their own despite the challenges in navigating the online system (Muhangi, 2012). The difficulties in the ability to navigate the online filing system quickly and efficiently without constantly referring to the help menus or consulting third parties results in prolonged time taken to complete the online filing (Ramoo, 2006). The tax payer may therefore be burdened by the time and effort spent learning the system and hence influence the adoption of the system (Lukwata, 2011).

\section{Impact of Perceived Security Risks Concerns on Tax Compliance}

The dependent on the third parties to assist a tax payer undertake online tax returns has the effect of the tax payer losing data privacy (Lai \& Choong, 2010). The taxpayer need to reveal personal financial details about his business such as the income derived from the business (Lukwata, 2011). A majority of the taxpayers may not be comfortable divulging such information to third parties who are not connected to their business (Ramoo, 2006). This is because it exposes them to security risk of being robbed. In this context, the taxpayer may opt to fill the manual tax returns in a bid to protect the privacy of his data (Ssetuba, 2012). The lack of the computer literacy in general and the lack of confidence around the online filing system may lead to psychological predispositions that may influence the adoption of electronic filing (Muhangi, 2012). For example, Mandola (2013) argues that a feeling of increased anxiety and stress due to lack of experience or comfort with using technology or feeling threatened by technology could prevent a customer being inclined to adopt the e filing system.

Concerns over security issues or perceived risks on the usage of the online filing services inhabit its adoption. Ramoo (2006) argues that perceived risk influences the adoption and usage of the online filing. The perceived risk is defined as the taxpayers' perception on the reliability of the system's usefulness/functionality and the control of their personal data information in an online environment (Ramoo, 2006). In this context, taxpayers using the online could be concerned on whether third parties can access their personal tax information without their knowledge or permission (Geetha \& Sekar, 2012). The failure of the system to deliver on its objectives due to either technical issues or other reasons affects the potential users' adoption of the system. In this context, Kamarulzaman \& Azmi (2010) argues that the risk factor that taxpayers' perceived to have towards the system, which promise to complete their transaction securely and to maintain the privacy of their personal information, will affect their voluntary adoption of the e-filing system.

\section{Impact of Online Tax System Stability on Tax Compliance}

The online tax filing system must be stable to handle the high traffic during the peak times. In this context, Kamarulzaman \& Azmi (2010) argue that the online system must run smoothly and efficient during the 
peak times especially closer to the deadlines. The inability of the system to handle huge information during the peak hours and may change the perception of the users that the system in unreliable (Nakiwala, 2010). Customers in this context may thus opt to utilize the manual filing due to the perception that the system is always unreliable (Mugo, 2013). According to Azmi \& Bee (2010), improvement on the e filing systems that will enhance the tax payer's perceived ease of use, usefulness and reduced riskiness of the system are essential in the adoption of the e filing system. Mugo (2013) notes that reducing taxpayer's perception of risk in electronic filing not only increases their perception on the usefulness of the electronic filing but also leads them to adoption of the system.

Ramoo (2006) argues that computer anxiety affects the adoption of the electronic filing of tax returns. The computer anxiety is defined as the fear and the apprehension felt by an individual when considering the utilization of the computer technology or when actually using it (Nakiwala, 2010). There are two components of computer anxiety that is the cognitive and the emotive components. The cognitive component underlies the negative expectancies and the emotional expectancy leads to negative physiological reactions (Ramoo, 2006). The computer anxiety has been shown to impact on the perceived ease of use, computer use and computing skills which leads to the low adoption of the electronic filing system. The computer anxiety is most likely to be an issue among the illiterate, semi illiterate and the elderly taxpayers (Hussein et al., 2010). Some of the traders in the SME sector have relatively low education levels which may reduce their confidence around computer technologies such as the online filing system.

\section{Objective of The Study}

The specific objectives of the study were as follows;

1. To establish the impact of the computer literacy aspects of online tax filing on tax compliance among small and medium enterprises in Nakuru, Kenya

2. To examine the impact of perceived security risks concerns of online tax filing on tax compliance among small and medium enterprises in Nakuru, Kenya

3. To determine the impact of the online tax system stability of online tax filing on tax compliance among small and medium enterprises in Nakuru, Kenya

\section{Research Hypotheses}

The following research hypothesis guided the study;

$\mathbf{H}_{\mathbf{0 1}}$ : There is no significant relationship between computer literacy levels and tax compliance among small and medium enterprises in Nakuru, Kenya

$\mathbf{H}_{\mathbf{0 2}}$ : There is no significant relationship between perceived security risks concerns and tax compliance among small and medium enterprises in Nakuru, Kenya

$\mathbf{H}_{\mathbf{0 3}}$ : There is no significant relationship between online tax system stability and tax compliance among small and medium enterprises in Nakuru, Kenya

\section{Methodology}

According to Ada (2009), a research design refers to the explanation of the method adopted in carrying out of the research and is thus a plan or structure of any aspect of the research procedure. The descriptive research technique will be used in the study. According to Simiyu (2013) a descriptive study enables the current description of the phenomena being studied. On the other hand, Chepkangor (2012) argues that descriptive case studies are used to describe an event/process in its natural ambit and the main objectives is to answer how, who and what questions. This research technique is ideal in the context that the researcher was interested in examining the factors influencing the adoption of the online tax filing among the SMEs in Nakuru CBD. The questionnaires were used to describe an existing phenomena by asking individuals about the perception, attitudes and behaviour or values (Kipkenei, 2012). The target population of this study is the SMEs within Nakuru County. According to Kariuki (2013), there are about 20,355 registered SMEs within Nakuru County which were used as the target population for this study. This study employed Nassiuma's (2009) formula to calculate the size of the sample. The formula to scientifically derive the sample from the target population is illustrated hereunder.

$$
n=\frac{N C^{2}}{C^{2}+(N-1) e^{2}}
$$

Where

$\mathrm{n}=$ sample size

$\mathrm{N}=$ size of target population

$\mathrm{C}=$ coefficient of variation $(0.5)$

$e=$ error margin $(0.05)$

Substituting these values in the equation, estimated sample size (n) were: 
$\left.\mathrm{n} \quad=20,355(0.5)^{2} /\left(0.5^{2}+(20,355-1) 0.05^{2}\right)\right)$

$\mathrm{n}=99.51$ that is 100 respondents

The study used 100 respondents as the sample size.

The study utilized 100 sample size derived through the use of Nassiuma's (2009) formula. Therefore, 100 questionnaires were distributed to potential respondents. The questionnaires that were returned were 91 making a response rate of $91 \%$. This high response rate was attributed to efforts made to increase the response rate such as constant reminders through short text messages on the need to fill the questionnaires on time. The telephone contacts had been collected at the point of questionnaire distribution. A response rate of $91 \%$ was deemed sufficient as it exceeded the $80 \%$ minimum threshold recommended by researchers.

Computer Literacy Levels

\section{Findings and Discussions}

The frequency distribution of the computer literacy level were illustrated in Table 1

Table 1; Computer Literacy Levels

\begin{tabular}{|l|l|l|l|l|l|l|}
\hline & $\begin{array}{l}\text { The following computer literacy levels have } \\
\text { played a significant role in tax compliance } \\
\text { amongst SMEs; }\end{array}$ & $\begin{array}{l}\text { SA } \\
\text { Freq. (\%) }\end{array}$ & $\begin{array}{l}\text { A } \\
\text { Freq. (\%) }\end{array}$ & $\begin{array}{l}\text { U } \\
\text { Freq. (\%) }\end{array}$ & $\begin{array}{l}\text { D } \\
\text { Freq. (\%) }\end{array}$ & $\begin{array}{l}\text { SD } \\
\text { Freq. (\%) }\end{array}$ \\
\hline 5$)$ & Proficiency of internet usage & $43(47.3)$ & $25(27.5)$ & $14(15.4)$ & $9(9.9)$ & $0(0.0)$ \\
\hline 6$)$ & Basic computer trouble shooting skills & $16(17.6)$ & $35(38.5)$ & $20(22.0)$ & $20(22.0)$ & $0(0.0)$ \\
\hline 7$)$ & Understanding of itax site navigation process & $55(60.4)$ & $26(28.6)$ & $10(11.0)$ & $0(0.0)$ & $0(0.0)$ \\
\hline 8$)$ & Ability to use self-help menus on itax platform & $21(23.1)$ & $40(44.0)$ & $15(16.5)$ & $15(16.5)$ & $0(0.0)$ \\
\hline 9$)$ & Ability to determine successful application & $50(54.9)$ & $25(27.5)$ & $12(13.2)$ & $4(4.4)$ & $0(0.0)$ \\
\hline
\end{tabular}

In the context of the proficiency of internet usage affecting tax compliance, a majority of $47.3 \%$ of the respondents strongly agreed that it did affect tax compliance. This is attributable to the fact that the online tax returned is internet based and as such proficiency of internet usage is a key requirement. This also is the reason attributed to the minimum number of respondents that is $9.9 \%$ who disagreed that it affect tax compliance. The majority of the respondents $38.5 \%$ agreed that basic computer trouble shooting skills affected the tax compliance compared to $22 \%$ who disagreed. This is attributable to the fact that the online tax returns is a selfhelp and self-navigation module in which the user is needs to have little technical know-how in trouble shooting in times of challenges. On the other hand, a majority of $44 \%$ of the respondents agreed that ability to use selfhelp menus on itax platform affects the tax compliance. This high percentage is attributed to the module of online tax returns which is self-navigated at the itax platform with no onsite help from KRA officials. Finally, the ability to determine successful application affects tax compliance as agreed by a majority of $54.9 \%$ of the respondents.

Table 2; Means and Standard Deviation of Computer Literacy Levels

\begin{tabular}{|l|l|l|l|l|l|l|}
\hline & & $\mathbf{N}$ & Min & Max & Mean & Std.Dev. \\
\hline 5) & Proficiency of internet usage & 91 & 1 & 5 & 4.12 & 1.00 \\
\hline 6$)$ & Basic computer trouble shooting skills & 91 & 1 & 5 & 3.51 & 1.03 \\
\hline 7$)$ & Understanding of itax site navigation process & 91 & 1 & 5 & 4.49 & 0.68 \\
\hline 8$)$ & Ability to use self-help menus on itax platform & 91 & 1 & 5 & 3.73 & 0.99 \\
\hline 9$)$ & Ability to determine successful application & 91 & 1 & 5 & 4.32 & 0.86 \\
\hline & Valid N (listwise) & $\mathbf{9 1}$ & & & & \\
\hline
\end{tabular}

The means and standard deviations of computer literacy were examined. The respondents on average tended to agree that the proficiency of internet usage had an impact on the tax compliance levels due to a mean of 4.12 and a standard deviation of 1.00 . In the context of the basic computer trouble shooting, the respondents on average tended to agree that it impacted on tax compliance due to a mean of 3.51 and a standard deviation of 1.03. Similarly, the understanding of itax site navigation as impacting on the tax compliance levels had a majority of the respondents on average agreeing to the same due to a mean of 4.49 and a standard deviation of 0.68. On the other hand, in relations to the ability to use self-help menus of itax platform the respondents on average agreed that it had an impact on the tax compliance due to a mean of 3.73 and a standard deviation of 0.99. Finally, in relations to the ability to determine successful application had the respondents on average tending to agree due to a mean of 4.32 and a standard deviation of 0.86 . 


\section{Security Concerns}

The results for the security concerns were presented in Table 3;

Table 3; Frequency Distribution of Security Concerns

\begin{tabular}{|c|c|c|c|c|c|c|}
\hline & $\begin{array}{l}\text { The following security risks concerns have played a significant role in } \\
\text { tax compliance amongst SMEs; }\end{array}$ & $\begin{array}{l}\text { SA } \\
\text { Freq. } \\
(\%)\end{array}$ & $\begin{array}{l}\text { A } \\
\text { Freq. } \\
(\%)\end{array}$ & $\begin{array}{l}\text { U } \\
\text { Freq. } \\
(\%)\end{array}$ & $\begin{array}{l}\text { D } \\
\text { Freq. } \\
(\%)\end{array}$ & $\begin{array}{l}\text { SD } \\
\text { Freq. } \\
(\%)\end{array}$ \\
\hline 10) & $\begin{array}{l}\text { Uncomfortable revealing business information to cyber attendants for } \\
\text { assistance in tax filing }\end{array}$ & $\begin{array}{l}36 \\
(39.6)\end{array}$ & 31 & $\begin{array}{l}19 \\
(20.9)\end{array}$ & $\begin{array}{l}5 \\
(5.5)\end{array}$ & $\begin{array}{l}0 \\
(0.0)\end{array}$ \\
\hline 11) & $\begin{array}{l}\text { Information revealed to third parties e.g. cyber attendants during tax } \\
\text { retums may place my business at security risk }\end{array}$ & $\begin{array}{l}20 \\
(22.0)\end{array}$ & $\begin{array}{l}40 \\
(44.0)\end{array}$ & $\begin{array}{l}14 \\
(15.4)\end{array}$ & $\begin{array}{l}17 \\
(18.7)\end{array}$ & $\begin{array}{l}0 \\
(0.0)\end{array}$ \\
\hline 12) & $\begin{array}{l}\text { Information revealed to third parties e.g. cyber attendants during tax } \\
\text { retums may get to my competitors }\end{array}$ & $\begin{array}{l}48 \\
(52.7)\end{array}$ & $\begin{array}{l}29 \\
(31.9)\end{array}$ & $\begin{array}{l}11 \\
(12.1)\end{array}$ & 3 & $\begin{array}{l}0 \\
(0.0)\end{array}$ \\
\hline 13) & $\begin{array}{l}\text { Information revealed to third parties e.g. cyber attendants during tax } \\
\text { retums may place my personal security at risk }\end{array}$ & $\begin{array}{l}23 \\
(25.3)\end{array}$ & $\begin{array}{l}40 \\
(44.0)\end{array}$ & $\begin{array}{l}16 \\
(17.6)\end{array}$ & $\begin{array}{l}12 \\
(13.2)\end{array}$ & $\begin{array}{l}0 \\
(0.0)\end{array}$ \\
\hline 14) & $\begin{array}{l}\text { Information revealed to third parties e.g. cyber attendants may not be } \\
\text { handled professionally }\end{array}$ & $\begin{array}{l}18 \\
(19.8)\end{array}$ & $\begin{array}{l}34 \\
(37.4)\end{array}$ & $\begin{array}{l}19 \\
(20.9)\end{array}$ & $\begin{array}{l}20 \\
(22.0)\end{array}$ & $\begin{array}{l}0 \\
(0.0)\end{array}$ \\
\hline
\end{tabular}

A majority of $39.6 \%$ of the respondents strongly agreed that they were uncomfortable revealing business information to cyber attendants for assistance in tax filing. This can be attributed to the fact the information that would normally presented gives an overview of the financial performance of their businesses. On the other hand, a majority of $44 \%$ of the respondents agreed that information revealed to third parties during tax returns may place their businesses at security risk. This was attributed to the fact that the information presented discussed on the financial performance of their businesses which could be revealed by third parties to criminals. It was only a small percentage of $15.4 \%$ of the respondents who were uncertain on the given issue. Similarly, a majority of $52.7 \%$ of the respondents feared that the information presented to third parties during online tax filing may be revealed to their competitors. This is because handling of the data by third parties such as cyber attendants may be handled professionally. This is revealed by a majority of $37.4 \%$ of the respondents who felt that their data will not be handled professionally by cyber attendants. On the other hand, a majority of $44 \%$ of the respondents agreed that information given to third parties may place them at security risk. This is due to the fact that their information may find its way to criminals.

Table 4; Means and Standard Deviation of Security Concerns

\begin{tabular}{|c|c|c|c|c|c|c|}
\hline & & $\mathbf{N}$ & Min & Max & Mean & Std.Dev. \\
\hline 10) & $\begin{array}{l}\text { Uncomfortable revealing business information to cyber attendants for } \\
\text { assistance in tax filing }\end{array}$ & 91 & 1 & 5 & 4.07 & 0.90 \\
\hline 11) & $\begin{array}{l}\text { Information revealed to third parties e.g. cyber attendants during tax } \\
\text { returns may place my business at security risk }\end{array}$ & 91 & 1 & 5 & 3.69 & 1.01 \\
\hline 12) & $\begin{array}{l}\text { Information revealed to third parties e.g. cyber attendants during tax } \\
\text { returns may get to my competitors }\end{array}$ & 91 & 1 & 5 & 4.34 & 0.81 \\
\hline 13) & $\begin{array}{l}\text { Information revealed to third parties e.g. cyber attendants during tax } \\
\text { returns may place my personal security at risk }\end{array}$ & 91 & 1 & 5 & 3.81 & 0.96 \\
\hline \multirow[t]{2}{*}{ 14) } & $\begin{array}{l}\text { Information revealed to third parties e.g. cyber attendants may not be } \\
\text { handled professionally }\end{array}$ & 91 & 1 & 5 & 3.54 & 1.04 \\
\hline & Valid N (listwise) & 91 & & & & \\
\hline
\end{tabular}

The means and standard deviations of security concerns were examined. In this context, the respondents on average agreed that they were uncomfortable revealing business information to cyber attendants for assistance in tax filing as indicated through a mean of 4.07 and a standard deviation of 0.90 . The information revealed to third parties during tax returns placing the business at a security risk had the respondents on average tending to agree due to a mean of 3.69 and a standard deviation of 1.01. The respondents on average tended to agree that the information revealed to third parties during tax returns may get to the competitors due to a mean of 4.34 and a standard deviation of 0.81 . The information being revealed to third parties e.g. cyber attendants during tax returns leading to personal security of the SME owners had a mean of 3.81 and a standard deviation of 0.96 . This implied that on average the respondents tended to agree with the statement. Finally, in relations to the information revealed to third parties not being handled professionally, the respondents on average tended to agree due to a mean of 3.54 and a standard deviation of 1.04 .

Online Tax Returns System Stability

The frequency distribution of online tax returns system stability was examined using Table 5.

Table 5; Frequency Distribution of Online Tax Returns System Stability

\begin{tabular}{|l|l|l|l|l|l|l|}
\hline & $\begin{array}{l}\text { The following online tax returns system stability concerns have played a } \\
\text { significant role in tax compliance amongst SMEs; }\end{array}$ & $\begin{array}{l}\text { SA } \\
\text { Freq. } \\
(\boldsymbol{\%})\end{array}$ & $\begin{array}{l}\text { A } \\
\text { Freq. } \\
(\boldsymbol{\%})\end{array}$ & $\begin{array}{l}\text { U } \\
\text { Freq. } \\
(\boldsymbol{\%})\end{array}$ & $\begin{array}{l}\text { D } \\
\text { Freq. } \\
(\boldsymbol{\%})\end{array}$ & $\begin{array}{l}\text { SD } \\
\text { Freq. } \\
(\boldsymbol{\%})\end{array}$ \\
\hline 15$)$ & System hang-ups leads to delay in submission & 47 & 33 & 10 & 1 & 0 \\
& & $(51.6)$ & $(36.3)$ & $(11.0)$ & $(1.1)$ & $(0.0)$ \\
\hline 16$)$ & System hang ups leads to unwillingness to file returns & 26 & 39 & 17 & 9 & 0 \\
\hline
\end{tabular}


Influence of Online Tax Filing on Tax Compliance among Small and Medium Enterprises in Nakuru...

\begin{tabular}{|c|c|c|c|c|c|c|}
\hline & & $(28.6)$ & $(42.9)$ & $(18.7)$ & $(9.9)$ & $(0.0)$ \\
\hline 17) & System hang ups leads to inability to file without assistance & $\begin{array}{ll}42 \\
(46.2)\end{array}$ & $\begin{array}{l}27 \\
(29.7)\end{array}$ & $\begin{array}{l}13 \\
(14.3)\end{array}$ & $\begin{array}{l}9 \\
(9.9)\end{array}$ & $\begin{array}{l}0 \\
(0.0)\end{array}$ \\
\hline 18) & $\begin{array}{l}\text { System hang ups leads to incurrence of costs to pay third parties to file on my } \\
\text { behalf }\end{array}$ & $\begin{array}{l}22 \\
(24.2)\end{array}$ & $\begin{array}{ll}38 \\
(41.8)\end{array}$ & $\begin{array}{l}14 \\
(15.4)\end{array}$ & $\begin{array}{l}14 \\
(15.4)\end{array}$ & $\begin{array}{l}3 \\
(3.3)\end{array}$ \\
\hline 19) & System hang ups leads to compromise of information submitted & $\begin{array}{l}20 \\
(22.0)\end{array}$ & $\begin{array}{l}37 \\
(40.7)\end{array}$ & $\begin{array}{l}16 \\
(17.6)\end{array}$ & $\begin{array}{l}18 \\
(19.8)\end{array}$ & $\begin{array}{l}0 \\
(0.0)\end{array}$ \\
\hline
\end{tabular}

A majority respondents of $51.6 \%$ strongly agreed that the system hang ups led to delay in submission of tax returns submission. This is attributable to the fact that such delays leads to taxpayers postponing on the scheduled times to do their tax returns. On the other hand, a majority of $42.9 \%$ of the respondents indicated that the system hang ups lead to unwillingness to file returns. This is due to the frustration experienced when there are incidences of system challenges. This contrasted to a small percentage of $9.9 \%$ of the respondents who disagreed that system hang ups lead to unwillingness to file returns. A majority of $46.2 \%$ of the respondents strongly agreed that system hang ups led to inability to file returns without assistance from third parties. This is in view of the time expenditure making SMEs to outsource the services to specialized cyber cafes. This contrasted to a small percentage of $9.9 \%$ who disagreed that the system hang ups led to seeking of assistance from third parties. In relations to system hang ups leading to incurrence of costs to pay third parties to file on their behalf, a majority of the respondents that is $41.8 \%$ of the respondents agreed to the statement. Most of the third party assistance is sought from the cyber attendants who operate on commercial basis. This is contrasted to only $3.3 \%$ of the respondents who strongly disagreed. Finally, a majority of $40.7 \%$ of the respondents agreed that the system hang ups led to compromise of information submitted. This can be attributed to passing of the information to the third parties to assist in filing of returns.

Table 6; Means and Standard Deviation of Online Tax Returns System Stability

\begin{tabular}{|l|l|l|l|l|l|l|}
\hline & & N & Min & Max & Mean & Std. Dev. \\
\hline 15$)$ & System hang-ups leads to delay in submission & 91 & 1 & 5 & 4.38 & 0.72 \\
\hline 16$)$ & System hang ups leads to unwillingness to file returns & 91 & 1 & 5 & 3.90 & 0.93 \\
\hline 17$)$ & System hang ups leads to inability to file without assistance & 91 & 1 & 5 & 4.12 & 0.99 \\
\hline 18$)$ & $\begin{array}{l}\text { System hang ups leads to incurrence of costs to pay third parties to file } \\
\text { on my behalf }\end{array}$ & 91 & 1 & 5 & 3.68 & 1.10 \\
\hline 19$)$ & System hang ups leads to compromise of information submitted & 91 & 1 & 5 & 3.64 & 1.03 \\
\hline & Valid N (listwise) & $\mathbf{9 1}$ & & & & \\
\hline
\end{tabular}

The means and standard deviations of challenges of the online tax returns stability were also examined. The respondents on average tended to agree that the system hang ups lead to delay in submission of tax returns due to a mean of 4.38 and a standard deviation of 0.72 . Similarly, the respondents on average tended to agree that the system hang ups led to unwillingness to file returns due to a mean of 3.90 and a standard deviation of 0.93. In relations to the system hang ups leading to inability to file returns without assistance had the respondents on average tending to agree due to a mean of 4.12 and a standard deviation of 0.99. Similarly, the system hang ups leading to incurrence of costs to pay third parties to file on the SMEs behalf had the respondents on average agreeing to the statement due to a mean of 3.68 and a standard deviation of 1.10 . Finally, the system hang ups leading to compromise of information submitted had the respondents on average agreeing to the statement due to a mean of 3.64 and a standard deviation of 1.03.

Tax Compliance Levels

The frequencies of the tax compliance levels were examined using Table 7.

Table 7; Frequency Distribution of Tax Compliance Levels

\begin{tabular}{|l|l|l|l|l|l|l|}
\hline & $\begin{array}{l}\text { Diverse challenges in online tax returns have affected } \\
\text { the following dimensions of tax compliance levels; }\end{array}$ & $\begin{array}{l}\text { SA } \\
\text { Freq. (\%) }\end{array}$ & $\begin{array}{l}\text { A } \\
\text { Freq. (\%) }\end{array}$ & $\begin{array}{l}\text { U } \\
\text { Freq. (\%) }\end{array}$ & $\begin{array}{l}\text { D } \\
\text { Freq. (\%) }\end{array}$ & $\begin{array}{l}\text { SD } \\
\text { Freq. (\%) }\end{array}$ \\
\hline 20$)$ & Timeliness of tax returns filing & $41(45.1)$ & $28(30.8)$ & $16(17.6)$ & $6(6.6)$ & $0(0.0)$ \\
\hline 21$)$ & Accuracy of the filed information & $40(44.0)$ & $29(31.9)$ & $14(15.4)$ & $8(8.8)$ & $0(0.0)$ \\
\hline 22$)$ & Timely payment of tax due & $30(33.0)$ & $34(37.4)$ & $14(15.4)$ & $13(14.3)$ & $0(0.0)$ \\
\hline 23$)$ & Little costs in tax returns & $21(23.1)$ & $33(36.3)$ & $19(20.9)$ & $18(19.8)$ & $0(0.0)$ \\
\hline 24$)$ & Voluntary compliance with tax aspects & $45(49.5)$ & $31(34.1)$ & $11(12.1)$ & $4(4.4)$ & $0(0.0)$ \\
\hline
\end{tabular}

A majority of the respondents that is $45.1 \%$ strongly agreed that the timeliness of tax returns filing was affected by the diverse challenges of online tax returns compared with $6.6 \%$ who disagreed. Similarly, a majority of $44 \%$ of the respondents strongly agreed that the accuracy of the filed information was affected by the diverse challenges in online tax returns compared to only $8.8 \%$ of the respondents who disagreed. In relations to the diverse challenges of tax returns affecting the timely payments of tax due, a majority of $37.4 \%$ of the respondents agreed that the timeliness of tax payments was affected. Finally, the diverse challenges of online 
tax returns affected the voluntary compliance with tax aspects as indicated by $49.5 \%$ of the respondents who strongly agreed.

Table 8; Means and Standard Deviation of Tax Compliance Levels

\begin{tabular}{|l|l|l|l|l|l|l|}
\hline & & N & Min & Max & Mean & Std.Dev. \\
\hline 20$)$ & Timeliness of tax returns filing & 91 & 1 & 5 & 4.14 & 0.93 \\
\hline 21$)$ & Accuracy of the filed information & 91 & 1 & 5 & 4.10 & 0.97 \\
\hline 22$)$ & Timely payment of tax due & 91 & 1 & 5 & 3.89 & 1.02 \\
\hline 23$)$ & Low costs in tax returns & 91 & 1 & 5 & 3.62 & 1.05 \\
\hline 24$)$ & Voluntary compliance with tax aspects & 91 & 1 & 5 & 4.28 & 0.84 \\
\hline & Valid N (listwise) & 91 & & & & \\
\hline
\end{tabular}

The means and standard deviations of the tax compliance levels were examined. The challenges of online tax returns affecting the timeliness of tax returns filing had a mean of 4.14 and standard deviation of 0.93 . This implied that on average the respondents tended to agree that timeliness of tax returns filing was affected. Similarly, the respondents on average tended to agree that the accuracy of the filed information was affected by the challenges of online tax returns due to a mean of 4.10 and standard deviation of 0.97 . The timely payment of the tax due had the respondents on average tending to agree that it was affected by the challenges of the online tax returns due to a mean of 3.89 and a standard deviation of 1.02. The aspects of low costs in tax returns had the respondents on average agreeing to the same due to a mean of 3.62 and a standard deviation of 1.05. Finally, the respondents on average tended to agree that the voluntary compliance with tax aspects was affected by the online tax returns challenges due to a mean of 4.28 and a standard deviation of 0.84 .

\section{Multiple Linear Regression of Dependent Variables}

The multiple linear regressions was used to examine the cumulative effect of computer literacy, perceived security risks, and online tax returns systems stability on tax compliance of SMEs within Nakuru town. The multiple correlation coefficient (R) was positive and of a value of 0.954 indicating that there was a strong and positive correlation between the three independent variable cumulatively and the dependent variable. On the other hand, the coefficient of determination ( $R$ Square) indicates the variance on tax compliance attributed to the three independent variables is $91.1 \%$.

Table 9; Model Summary

\begin{tabular}{|l|l|l|l|l|}
\hline Model & R & R Square & Adjusted R Square & Std. Error of the Estimate \\
\hline 1 & $.954^{\mathrm{a}}$ & .911 & .908 & .21492 \\
\hline
\end{tabular}

The one way ANOVA was used to give an indication on whether the linear regression model was a good fit for data or the three independent variables were good predictors of the dependent variable. In this context since $\mathrm{F}$ $(3,87)=296.244, \mathrm{P}<0.05$ then the model was considered a good fit for the data.

Table 10; ANOVA of the Independent Variables

\begin{tabular}{|l|l|l|l|l|l|l|}
\hline \multicolumn{2}{|l|}{ Model } & Sum of Squares & df & Mean Square & F & Sig. \\
\hline \multirow{3}{*}{1} & Regression & 41.050 & 3 & 13.683 & 296.244 & $.000^{\mathrm{b}}$ \\
\cline { 2 - 7 } & Residual & 4.019 & 87 & .046 & & \\
\cline { 2 - 6 } & Total & 45.069 & 90 & & & \\
\hline
\end{tabular}

The unstandardized coefficients of the model were examined with a view of giving the effect of computer literacy, security perceptions, and online returns system stability on the tax compliance levels at an independent level. The three independent variables had positive effect on the dependent variable as indicated by their coefficients in the below linear regression equation;

Tax Compliance Levels $=-0.122+0.874\left(x_{1}\right)+0.143\left(x_{2}\right)+0.118\left(x_{3}\right)$ where

$x_{1}=$ Computer Literacy

$x_{2}=$ Security Concerns

$x_{3}=$ Online Tax Returns System Stability

The coefficient of intercept -0.122 indicates that the tax compliance levels would decline by 0.122 if the computer literacy, security concerns, and online tax returns system stability were at zero. The beta coefficient of computer literacy is 0.874 indicating that a unit increase in computer literacy would lead to a 0.874 increase in tax compliance. Similarly, the beta coefficient of security is 0.143 implying that a unit increase in security would lead to a 0.143 increase in tax compliance levels. Finally, a unit increase in online tax returns 
systems stability would lead to a 0.118 increase in tax compliance levels. However, the examination of the $\mathrm{p}$ value implies that it was only computer literacy that had significant effect on the tax compliance with the other variables kept constant since its $\mathrm{p}<0.005$.

Table 11; Coefficients

\begin{tabular}{|c|c|c|c|c|c|c|}
\hline \multirow{2}{*}{\multicolumn{2}{|c|}{ Model }} & \multicolumn{2}{|c|}{ Unstandardized Coefficients } & \multirow{2}{*}{$\begin{array}{l}\text { Standardized Coefficients } \\
\text { Beta }\end{array}$} & \multirow[t]{2}{*}{$\mathrm{t}$} & \multirow[t]{2}{*}{ Sig. } \\
\hline & & $\mathrm{B}$ & Std. Error & & & \\
\hline \multirow[t]{4}{*}{1} & (Constant) & -.122 & .149 & & -.818 & .415 \\
\hline & Computer Literacy & 0.874 & .095 & .926 & 10.580 & .000 \\
\hline & Security & .143 & .122 & .128 & 1.174 & .244 \\
\hline & Stability & .118 & .108 & .101 & 1.091 & .278 \\
\hline
\end{tabular}

The research hypothesis testing was undertaken through the use of the t test through the examination the $\mathrm{p}$ value of the multiple linear regression table. In the context of where the $\mathrm{p}$ value is less than 0.05 significance level then the null hypothesis was rejected. The following hypotheses were tested;

$\mathrm{H}_{01}$ : There is no significant relationship between computer literacy levels and tax compliance among small and medium enterprises in Nakuru, Kenya

The $\mathrm{p}$ value for computer literacy levels was 0.000 and therefore the null hypothesis $\left(\mathrm{H}_{01}\right)$ was rejected since $\mathrm{p}$ value $<0.05$. The study therefore found that there was a significant relationship between computer literacy levels and tax compliance amongst SMEs in Nakuru, Kenya.

$\mathrm{H}_{02}$ : There is no significant relationship between perceived security risks concerns and tax compliance among small and medium enterprises in Nakuru, Kenya

The $\mathrm{p}$ value of perceived security risks was 0.244 and therefore the null hypothesis $\left(\mathrm{H}_{02}\right)$ was accepted since $\mathrm{p}$ value $>0.05$. The study therefore found that there was no significant relationship between perceived security risks and tax compliance amongst SMEs in Nakuru, Kenya.

$\mathbf{H}_{03}$ : There is no significant relationship between online tax system stability and tax compliance among small and medium enterprises in Nakuru, Kenya

The $\mathrm{p}$ value of perceived security risks was 0.278 and therefore the null hypothesis $\left(\mathrm{H}_{03}\right)$ was accepted since $\mathrm{p}$ value $>0.05$. The study therefore found that there was no significant relationship between online tax system stability and tax compliance amongst SMEs in Nakuru, Kenya.

\section{Recommendations}

The study concluded that that computer literacy levels have significant influence on tax compliance levels amongst the SMEs within Nakuru. In the context of security, the study concluded that security risks concerns did not have significant influence on tax compliance levels amongst the SMEs within Nakuru Town. In the context, the study concluded that online tax returns system stability did not have significant influence on tax compliance levels amongst the SMEs within Nakuru Town. The study recommends that computer literacy levels should be emphasized by KRA in order to improve on tax compliance levels. This was due to high level of significance between computer literacy levels and tax compliance levels. The study recommends further examination on the factors that affect tax compliance levels. The study found that the computer literacy levels significantly affected the tax compliance levels and as such the study recommends a further examination on how KRA can deal with the issue with a view of improving tax compliance.

\section{References}

[1]. Ada, A. (2009). Effects of Information Technology on the Efficiency of Tax Administration ( A Case Study of Enugu State Board of Internal Revenue). International Journal of Business and Management Invention, 3(1), 1-10.

[2]. Adeyemo, K. (2012). Frauds In Nigerian Banks: Nature, Deep-Seated Causes, Aftermaths And Probable Remedies. Mediterranean Journal of Social Sciences, 3(May), 279-290.

[3]. Akuku, A. O. (2009). The Role Played by Microfinance Institutions in the Funding of Business Sart Ups for Micro Entrepreneurs: A Case Study of Gikomba Market Micro Entrepreneurs. International Journal of Economics and Finance, 2(2), 1-50.

[4]. Auyat, M. (2013). E Tax Service System and Its Adoption at Uganda Revenue Authority. Interdisciplinary Journal of Contemporary Research in Business, 2(4), 36-39.

[5]. Azmi, A., \& Bee, N. (2011). The Acceptance of the e-Filing System by Malaysian Taxpayers : A Simplified Model. Electronic Journal of E-Government, 8(1), 13-22.

[6]. Azmi, A., \& Kamarulzaman, Y. (2010). Adoption of tax e-filing: A conceptual paper. African Journal of Business Management, 4(3), 599-603.

[7]. Babajide, A. (2011). Effects of Microfinancing on Micro and Small Enterprises (MSEs) in Southwest Nigeria. Interdisciplinary Journal of Contemporary Research in Business, 2(2), 25-27.

[8]. Bett, M. (2013). Effects of Inflation and Interest Rates on Mortgage Finance Offered by Commercial Banks in Kenya. Journal of 
Modern Accounting and Auditing, 2(2), 25-32.

[9]. Chepkangor, D. (2012). Determinants of Consumer Choice of Commercial Banks : A Case of Kenya Commercial Bank in Nakuru Town. International Journal of Financial Research, 4(1), 2-7.

[10]. Etemesi, V. (2009). Factors that influence the performance of mobile phone operators in Kenya: A case of Zain Kenya LTD. International Journal of Business and Management Invention, 2(5), 7-9. Retrieved from business.uonbi.ac.ke/node/1431

[11]. Ferreira, P. (2008). An Overview of the New Tax Return Form and Tax System. International Journal of Business and Management Invention, 2(3), 35-37.

[12]. Gathungu, M., \& Ratemo, Z. (2011). An assessment of the impact of Corporate Social Responsbility on the strategic intent at Standard Chartered Bank Kenya. International Journal of Education and Research, 1(5), 1-20.

[13]. Geetha, R., \& Sekar, M. (2012). E-Filing of Income Tax : Awareness and Satisfaction level of individual Tax payers in Coimbatore city , India. Research Journal of Management Sciences, 1(4), 6-11.

[14]. Hussein, R., Mohamed, N., Ahlan, A. R., Mahmud, M., \& Aditiawarman, U. (2010). An Integrated Model on Online Tax Adoption in Malaysia. International Journal of Asian Social Science, 3(2), 1-16.

[15]. Ibrahim, I. (2012). Factors Underpinning Usage Behaviour of an Electronic Filing System: The Case of Malaysian Personal Taxpayers. International Journal of Asian Social Science, 4(3), 1-21.

[16]. Kamarulzaman, Y., \& Azmi, A. A. C. (2010). Tax E-filing Adoption in Malaysia : A Conceptual Model. Journal of Accounting and Finance, 3(4), 25-29.

[17]. Kariuki, G. (2013). An Assessment of Internet Usage on Small and Medium Enterprises (SMEs) in Nakuru Town Constituency. International Multidisciplinary Journal, 2(3), 52-64.

[18]. Kenya Revenue Authority. (2014). Frequently Asked Questions.

[19]. Keshta, M., Hassan, T., \& Alghalayini, S. (2013). The Effect of The Internal Auditing on Financial Performance (Apllied Study on Bank of Palestine). International Journal of Business and Public Management, 1(1).

[20]. Kipkenei, R. K. (2012). Analysis of Policy Effectiveness as a Strategic Management Tool on Microfinance Institutions in Kenya: A Case of MFI'S in Nakuru Municipality. Journal of Emerging Issues in Economics, Finance and Banking (JEIEFB), 2(3), 28-29.

[21]. Lai, M., \& Choong, K. (2010). Motivators, Barriers and Concerns in Adoption of Electronic Filing System: Survey Evidence from Malaysian Professional Accountants. American Journal of Applied Sciences, 3(4), 10-15.

[22]. Luchinga, L. (2014). The Effect of Working Capital Management on the Profitability of Agricultural Firms Listed in Nairobi Securities Exchange. Journal of Business and Management, 2(1), 37-45.

[23]. Lukorito, G. M. (2012). Information Security Threats and E-Government Initiatives at the Kenya Revenue Authority (KRA). International Journal of Business, Humanities and Technology, 2(2), 7-9.

[24]. Lukwata, H. (2011). The Influence of Electronic Tax Filing System and Tax Compliance and Tax Collection. International Journal of Business and Management Invention, 3(2), 5-7.

[25]. Mandola, V. (2013). Factors Influencing the Adoption and Use of Integrated Tax Management System by Medium and Small Taxpayers in Nairobi Central Business District, Kenya. Interdisciplinary Journal of Contemporary Research in Business, 2(2), 1215.

[26]. Maobe, D. (2013). The Effects of Group Liability Lending on Performance of Medium and Small Enterprises in Nairobi Uhuru Market. Journal of Sustainable Development in Africa, 3(3), 9-13.

[27]. Matama, R. (2008). Corporate Governance and Fiancial Performance of Selected Commercial Banks in Uganda. Journal of Sustainable Development in Africa, 1(2), 9-10.

[28]. Mugo, F. (2013). The Effect of Electronic Tax Registers on Value Added Tax Administration in Kenya: A Case Study of Hotels in Nairobi County. Journal of Accounting and Finance, 3(4), 15-17.

[29]. Muhangi, D. (2012). Taxation and Growth of Small Scale Business Enterprises in Uganda: A Case Study of Kikuubo Market, Central Division in Kampala District. International Journal of Business and Management Invention, 2(3), 45-47.

[30]. Mulili, B. M. (2011). Towards the best corporate governance practices model for public universities in developing countries : the case of Kenya Public Universities in Developing Countries: The Case of Kenya. Journal of Sustainable Development in Africa, 2(3), 17-19.

[31]. Mulumba, J. (2011). Credit Policy, Managerial Competence, Outreach and Customer Retention in Microfinance Institutions: A Study of Microfinance Institutions in Uganda. Interdisciplinary Journal of Contemporary Research in Business, 2(4), 25-30.

[32]. Mwanje, S. (2010). Career Development and Staff Motivation in the Banking Industry: A Case Study of Bank of Uganda. Interdisciplinary Journal of Contemporary Research in Business, 2(3), 47-56.

[33]. Nakiwala, A. (2010). Tax Competencies, Compliance Costs and Income Tax Compliance Among SMEs in Uganda. International Journal of Business and Public Management, 1(2), 25-27.

[34]. Natukunda, J. (2010). Microfinance Credit Lending Terms, Networks and Performance of Women Enterprises: The Case of Wakiso District. Journal of Accounting and Finance, 2(2), 23-25.

[35]. Nyaga, K. (2015). The impact of Mobile Money Services on the performance of Small and Medium Enterprises in an urban town in Kenya. International Journal of Business and Management Invention, 3(2), 23-24.

[36]. Odongo, B. (2014). Impact of Taxes on Performance of Small Scale Business Enterprises in Ntungamo Town Council. Journal of Economics and International Business Research, 3(4), 25-27.

[37]. Omino, B. (2014). The Effect of Working Capital Management and Profitability of Retail Stores in Migori County- Kenya. International Review of Management and Business Research, 2(2), 19-25.

[38]. Osebe, R. (2013). An Analysis of Factors Affecting Tax Compliance in the Real Estate Sector in Kenya: A Case Study of Real Estate Owners in Nakuru Town. Journal of Emerging Issues in Economics, Finance and Banking (JEIEFB), 1(4), 7-9.

[39]. Ramoo, V. (2006). Determinants of Perceived Ease of Use of E-Filing. Journal of Emerging Issues in Economics, Finance and Banking (JEIEFB), 3(1), 17-20.

[40]. Razak, M. (2009). Taxpayers' Attitude In Using E-Filing System: Is There Any Significant Difference Among Demographic Factors? Journal of Internet Banking and Commerce, 14(1), 1-13.

[41]. Simiyu, D. (2013). Challenges Affecting Collection of Turnover Tax in Nairobi County-Kenya. International Journal of Business and Social Research, 3(4), 25-27.

[42]. Waliula, R. (2013). Relationship Bteween Microcredit and the Growth of Small and Medium Enterprises in Kenya. International Journal of Business and Management Invention, 2(3), 30-33.

[43]. Wangu, M. P. (2011). Access to Finance and Performance of Small and Medium Enterprises. International Journal of Business and Public Management, 4(2), 17-19.

[44]. Young, N. (2012). The Effect of Global E Commerce on Taxation Legiuslation and The Permanent Establishment Concept in South Africa. International Journal of Economics and Finance, 3(3), 10-12. 